\title{
PENERAPAN MODEL PEMBELAJARAN PROBLEM BASED LEARNING (PBL) BERBASIS LESSON STUDY UNTUK MENINGKATKAN PEMAHAMAN KONSEP DAN AKTIVITAS MAHASISWA PENDIDIKAN BIOLOGI UNIVERSITAS NEGERI MALANG PADA MATA KULIAH PENGEMBANGAN KURIKULUM
}

\author{
Erfitra Rezqi Prasmala ${ }^{1}$ \\ ${ }^{1}$ Program Studi Pendidikan Biologi IKIP Budi Utomo Malang, Jalan Simpang Arjuno 14-B \\ Malang 65112: Telp. 0341-323214, 085655578808 \\ e-mail: dphitlah@yahoo.co.id
}

\begin{abstract}
The aim of research to improve the activity and student understanding of concepts Curriculum Development at S1 Department of Biology, State University of Malang by applying the model of Problem Based Learning (PBL) based Lesson study. Type of research is action Action Research (PTK) based Lesson study. PBL model application can increase the activity and student understanding of concepts. Based on the discussion of the suggestions in this study was not able to be done independently entirely by students as well as the need for time management as effectively as possible.
\end{abstract}

\begin{abstract}
ABSTRAK
Tujuan penelitian untuk meningkatkan aktivitas dan pemahaman konsep mahasiswapada matakuliah Pengembangan Kurikulum di S1 Jurusan Biologi Universitas Negeri Malangdengan menerapkanmodel Problem Based Learning (PBL) berbasis Lesson study. Jenis penelitian yang dilakukan adalah Penelitian Tindakan Tindakan (PTK) berbasis Lesson study. Penerapan model PBLdapat meningkatkan aktivitas dan pemahaman konsep mahasiswa. Berdasarkan pembahasan saran yang diajukan dalam penelitian ini adalah tidak bisa dilakukan secara mandiri sepenuhnya oleh mahasiswa serta perlu adanya manajemen waktu seefektif mungkin.
\end{abstract}

Kata kunci: Problem Based Learning (PBL), Lesson Study, Aktivitas Mahasiswa, Pemahaman Konsep Mahasiswa,

\section{PENDAHULUAN}

Kurangnya aktifnya mahasiswa selama pembelajaran akan mempengaruhi pemahaman mahasiswa. Pembelajaran pengembangan kurikulum menuntut dosen agar mampu menfasilitasi pembelajaran yang mendidik, menggiring mahasiswa menemukan konsep, dan membimbing mahasiswa untuk menyusun suatu produk pengembangan perangkat pembelajaran.
Peningkatan aktivitas mahasiswa akan melatih mahasiswa untuk mengkonstruk pengetahuan yang mereka peroleh, melatih mahasiswa untuk aktif berpikir dan meningkatkan hasil belajar mahasiswa (Nurhadi, Senduk Gerrad., 2004). Pembelajaran model PBL akan memicu dan mendorong mahasiswa untuk berpikir dengan menunjukkan berbagai masalah dilingkungan sekitar mereka sehingga 
Model PBL akan memberikan kesempatan pada mahasiswa untuk menerima pengalaman nyata selama proses pembelajaran dalam penyusunan pemetaan dan perumusan indikator serta tujuan pembelajaran.

\section{METODE}

Pendekatan yang digunakan dalam penelitian ini adalah pendekatan kualitatif dan menggunakan analisis dengan pendekatan induktif. Jenis penelitian yang dilakukan adalah Penelitian Tindakan Kelas (PTK) berbasis Lesson study. Penelitan dilakukan Universitas Negeri Malang pada kelas matakuliah Pengembangan Kurikulum mahasiswa jurusan Biologi pada bulan Oktober 2013 dengan subjek penelitian mahasiswa yang sedang menempuh matakuliah pengembangan kurikulum terdiri dari 15mahasiswa. Instrumen yang digunakan dalam penelitian ini terdiri dari lembar observasi aktivitas mahasiswa, lembar observasi pemahaman konsep, catatan lapangan, dan keterlaksanaan pembelajaran dosen. Penelitian ini dilaksanakan dalam dua siklus, setiap siklus terdiri dari 4 tahap yaitu perencanaan tindakan, pelaksanaan tindakan, observasi dan refleksi. Tahap perencanaan siklus I dilaksanakan sesuai dengan hasil refleksi dari tahap observasi awal. Tahap perencanaan siklus II dilaksanakan sesuai dengan hasil refleksi dari siklus I. Data dianalisis secara kualitatif deskriptif. Pada setiap pertemuan selalu dilakukan tahap Plan, do dan see. Setiap sebelum pertemuan dilakukan kegiatan plan dan diakhir pertemuan dilakukan kegiatan see untuk memperbaiki di kegiatan pembelajaran pada pertemuan berikutnya.

\section{HASIL DAN PEMBAHASAN}

\section{Keterlaksanaan Pembelajaran model}

Problem Based Learning (PBL)

Aktivitas dosen yang diamati berkaitan dengan indikator-indikator yang terdapat dalam lembar observasi keterlaksanaan pembelajaran dosen, aktivitas mahasiswa juga diamati sebagai respon terhadap indikator-indikator yang dilaksanakan oleh dosen. Persentase keterlaksanaan pembelajaran dengan model PBLpada siklus I dapat dilihat pada Tabel 1.

Tabel 1 Persentase Keterlaksanaan Pembelajaran Siklus I

\begin{tabular}{lc}
\hline $\begin{array}{l}\text { Kategori } \\
\text { Keterlaksanaan }\end{array}$ & $\begin{array}{c}\text { Persentase } \\
\text { keterlaksanaan } \\
(\mathbf{\%})\end{array}$ \\
\hline Observer I & 80 \\
\hline Observer II & 80 \\
\hline Observer III & 80 \\
\hline Observer IV & 80 \\
\hline Rerata (\%) & 80 \\
\hline
\end{tabular}

Penerapan model PBL terdiri dari 5 tahapyaitu,pendahuluan yang diawali dengan mengorientasikan mahasiswa 
kepada masalah, mengorganisisr mahasiswa untuk belajar, membimbing untuk melakukan investigasi kelompok, mengembangkan dan menyajikan hasil karya dan di akhir pembelajaran menganalisis dan mengevaluasi proses. Tahapan-tahapan tersebut dilaksanakan secara runtut sehingga tujuan dalam penerapan model PBL bisa tercapai.

Dosen melakukan apersepsi pada tahap pendahuluan untuk mengetahui kemampuan awal mahasiswa. Kemampuan awal mahasiswa tersebut dosen mencoba mengarahkan mahasiswa untuk mengetahui konsep pembelajaran yang akan dipelajari. Dosenmembimbing mahasiswa untuk mengorientasikan mahasiswa untuk menemukan berbagai masalah sehingga mampu mengidentifikasi topik yang akan dipelajari.mahasiswa akan memilih berbagai subtopik yang sudah digambarkan oleh dosen terhadap masalahmasalahdi lingkungan sekitar. Berbagai masalah di lingkungan sekitar, kemudian mahasiswaakan menentukan topik masalah apa yang akan mereka pecahkan melalui investigasi yang dilakukan dalam kelompok yang heterogen. Dosen berperan sebagai penyaji masalah (Arends,R.I., 2008). Dosen berperan sebagai pengarah mahasiswa menuju masalah (Arends,R.I., 2008) masalah-masalah yang adadi lingkungan sekitar. Penyajian masalah bertujuan untuk membuka daya pikir mahasiswa terhadap keadaan lingkungan sekitarnya dengan demikian diharapkan mahasiswaakan menjadi lebih peka dengan kondisi lingkungan sekitarnya.

Tahap selanjutnya dosenmengorganisi siswa untuk belajar dimulai dengan membagi menjadi kelompok-kelompok yang heterogen. Heterogenitas kelompok didasarkan pada kemampuan kognitif dan kesamaan minat. Pembentukan kelompok secara heterogen dilakukan untuk memupuk kerjasama antar mahasiswa dan adanya transfer informasi dari mahasiswa. Dalam kelompok mahasiswa yang heterogen mahasiswa dengan kemampuan lebih berperan sebagai tutor sebaya bagi mahasiswa yang memiliki kemampuan yang kurang, dengan demikian diharapkan kelompok yang heterogen dapat memperlancar proses pembelajaran (Arends,R.I., 2008).Dosen membantu mahasiswa mendefinisikan dan mengoorganisir tugas belajar yang berhubungan dengan masalah yang akan diselidiki. Mahasiswa dibimbing untuk menentukan judul, merumuskan masalah dan menentukan tujuan penelitian. Mahasiswa diarahkan untuk memperhatikan KD dalam permendikbud 2013, Pada siklus I mahasiswa masih sulit untuk menganalisis KD dan mkelihat keterpaduan antar materi sehingga memperlihatkan pembelajaran IPA SMP yang terpadu, karena pada pembelajaran 
sebelumnya mahasiswa lebih sering membuat perencanaan pembelajaran dengan melihat rancangan pembelajaran terdahulu, kemudian tingga disesuaikan dengan format dari dosen. Mahasiswa belum pernah menganalisis KD dari awal untuk merencanakan suatu pembelajaran. Pada siklus II mahasiswa sudah lebih terbiasa untuk membuat perencanaan dengan tepat, pada siklus II dilanjutkan dengan membuat indikator dan tujuan pembelajaran yang sesuai dengan pemetaan, dengam membuat indikator yang sesuai dan operasional sehingga mudah untuk diukur.

Tahapan selanjutnya adalah implementasi yang mana pada tahap ini ada kegiatan pembimbingan untuk melakukan investigasi,mahasiswa melaksanakan rencana yang telah dirumuskan pada saat merencanakan kerjasama. Mahasiswa dibimbing oleh dosen untuk merumuskan solusi dan memberikan bantuan jika diperlukan. Mahasiswa melaksanakan penyelidikan untuk mendapatkan penjelasan dan pemecahan masalah dari masalah di lingkungan sekitar. Pada pembelajaran dosen harus mampu membuat variasivariasi dalam pembelajaran karena hal ini dapat memberikan dampak yang positif bagi mahasiswa, karena mahasiswa tidak akan bosan dan proses belajar akan lebih efisien. "Pembelajaran yang monoton dapat menurunkan minat dan perhatian mahasiswa terhadap kegiatan pembelajaran" (Hasibuan dan Moedjiono. 2008).

Tahap selanjutnya adalah mengembangkan dan menyajikan hasil karya hasil pengerjakan yang didapatkan, kemudian mahasiswa merencanakan agar dapat diringkas dalam suatu penyajian yang menarik di depan kelas. Tahap ini mahasiswa diminta untuk menganalisis pengerjakan yang sudah di peroleh, sehingga bisa mengaitkan antar materi.Dosen berusaha membimbing mahasiswa untuk membahas data pengamatan yang didapat dari penyelidikan yang dilakukan oleh mahasiswa. Mahasiswa diminta untuk menyimpulkan, setelah melakukan analisis data pengamatan. Mahasiswa diminta untuk mempersiapkan materi yang akan dipresentasikan. Menurut Nurhadi, Senduk Gerrad (2004)Mahasiswa dituntut untuk mampu memecahkan sendiri masalah yang mereka temukan, dan pemecahan masalah dilakukan melalui suatu penyelidikan yang mereka lakukan. Pada tahap ini setiap kelompok menyajikan suatu presentasi yang menarik dari berbagai topik yang telah dipelajari agar semua mahasiswa dalam kelas saling terlibat dan mencapai suatu perspektif yang luas mengenai topik. Pada tahap ini mahasiswaakan saling bertukar hasil penyelidikan yang telah 
mereka selidiki, penyelidikan dilakukan untuk menemukan pemecahan terhadap masalah di lingkungan sekitar.

Tahapan selanjutnya adalah menganalisis dan mengevaluasi proses, pada tahap ini dosen membantu mahasiswa melakukan refleksi/evaluasi terhadap penyelidikan mereka dan proses-proses yang mereka gunakan. Selama tahap ini, dosen meminta mahasiswa untuk mengkonstruksi pemikiran dan kegiatan mereka selama berbagai tahap pembelajaran. Menurut Dimyati dan Mudjiono (1994) salah satu faktor yang berpengaruh terhadap hasil belajar mahasiswa adalah strategi yang memberikan hasil baik adalah strategi pembelajaran yang banyak melibatkan mahasiswa untuk berfikir, berargumen, berbicara, dan mengutarakan gagasannya.

\section{Aktivitas Mahasiswa}

Penerapan pembelajaran dengan model Problem Based Learning (PBL) dilakukan mulai siklus I sampai dengan siklus II, maka dapat diketahui bahwa aktivitas mahasiswa mengalami peningkatan. Pada tahap tindakan yang dilakukan pada siklus I menunjukkan rerata persentase klasikal indikator berkomunikasi mencapai 80,20\%, indikator kemampuan dalam bekerjasama mencapai $72,92 \%$ dan indikatorDiskusi dan presentasi mencapai 72,91\%dari seluruh indikator tersebut didapat rata-rata aktivitas mahasiswa pada siklus I mencapai $80,729 \%$ yang termasuk dalam kategori baik.

Pembelajaran yang dilakukan pada siklus II menunjukkan rerata persentase klasikal indikator berkomunikasi mencapai $95,833 \%$, indikator kemampuan dalam bekerjasama mencapai $91,66 \%$ dan indikator Diskusi dan presentasi mencapai 95,35\%dari seluruh indikator tersebut didapat rata-rata aktivitas mahasiswa pada siklus II mencapai 95,05\% yang termasuk dalam kategori sangat baik.

Untuk memperjelas maka akan disajikan Gambar 1tentang aktivitas mahasiswa. 


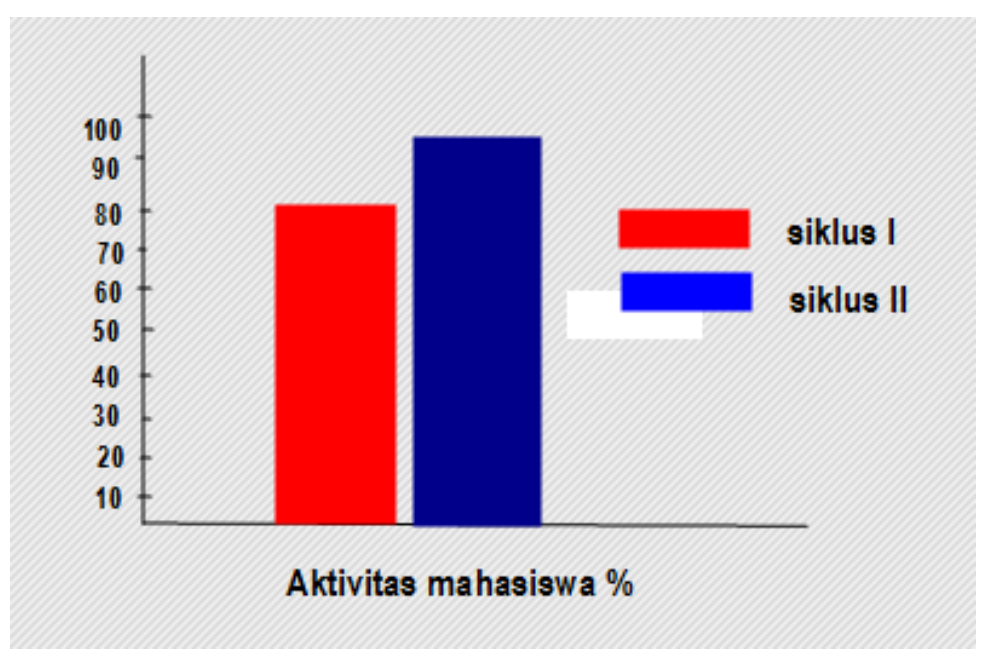

Gambar 1Persentase Aktivitas Mahasiswa

Dari Gambar 1 menunjukkan bahwa model PBL dapat meningkatkan aktivitasmahasiswa. Arend, R.I (2008) menjelaskan bahwa tujuan intruksional dari PBL adalah mengembangkan keterampilan investigasi dan keterampilan mengatasi masalah. PBL melatih mahasiswa untuk terampil bekerja ilmiah dalam pembelajaran, baik pada saat penemuan masalah, investigasi yang dilakukan sampai dengan menyajikan pemecahan masalah yang mereka temukan, sehingga siswa akan aktif selama pembelajaran.

Pelaksanaan model PBL masih banyak membutuhkan bimbingan dosen, bukan dosen mendominasi dalam pembelajaran tapi proses pendampingan mahasiswa dalam setiap pembelajaran masih dibutuhkan untuk mengarahkan mahasiswa dalam menemukan konsep dan proses sains. Pembelajaran dengan model
PBL masih sulit untuk diterapkan jika benar-benar dilakukan secara mandiri oleh mahasiswa, melainkan membutuhkan peran dosen untuk membimbing dalam pembelajaran, untuk menfokuskan ke topik yang dibahaskan.

\section{Pemahaman Konsep}

Kemampuan kognitif dari siklus I ke siklus II juga mengalami peningkatan. Pemahaman konsepmeningkat sebesar 10,625\%. Pada siklus ! sebesar 84,375 meningkat pada siklus II menjadi 95\%.Untuk memperjelas maka akan disajikan Gambar 2tentang kemampuan kognitif mahasiswa.

Gambar 2 menunjukkan adanya peningkatan pemahaman konsep. Pemahaman konsep setiap mahasiswa memang berbeda-beda yang dilihat dari produk yang dikembangkan selama pembelajaran, tetapi, mahasiswa mampu 
meningkatkan pemahaman konsep mereka pada siklus II. Menurut Muslikhatin (2005), hasil belajar mahasiswa satu dengan yang lainnya tidak sama, tinggi rendahnya hasil belajar yang dicapai mahasiswa tergantung dari proses belajar yang terjadi pada mahasiswa tersebut. Hasil belajar ini bisa juga dipakai untuk melihat pemahaman konsep mahasiswa. Seorang mahasiswa dikatakan memiliki pemahaman konsep yang baik bila mahasiswa tersebut mampu menunjukkan suatu perubahan tingkah laku yang positif dari proses belajar yang telah dilakukan. Pembelajaran dengan pemberian masalah dan keaktivan akan mendorong mahasiswa untuk menginterprestasikan dan menjelaskan berbagai fenomena dunia nyata untuk mengkonstruk produk pengemabanganmahasiswa selama pembelajaran (Arends, R.I., 2008). Pembelajaran dengan model PBLakan menuntut mahasiswa untuk merancang, memecahkan masalah, membuat keputusan, melakukan kegiatan investigasi, serta memberikan kesempatan kepada mahasiswa untuk bekerja mandiri (Wena, 2009). Arends (2008) menyatakan bahwa pembelajaran dengan pemberian masalah akan memberikan orientasi kepada mahasiswa tentang permasalahannya, mengorganisir mahasiswa untuk meneliti, membantu investigasi mandiri dan kelompok, mengembangkan dan mempresentasikan hasil penyelidikan, menganalisis dan mengevaluasi pekerjaan (Arend, R.I., 2008).

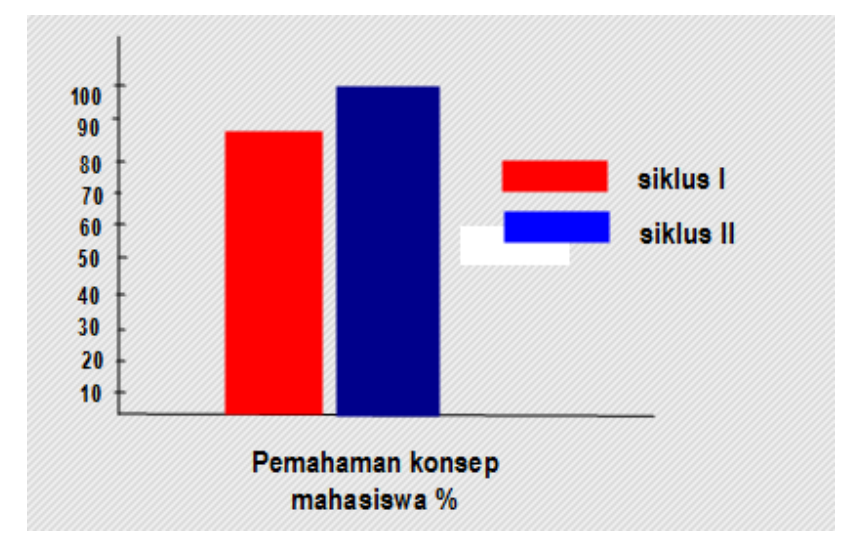

Gambar 2Pemahaman Konsep Mahasiswa

Penerapan model PBL yang dapat meningkatkan konsepmahasiswadan meningkatkanaktivitas pemahaman dapat mahasiswa.
Pembelajaran yang dilakukan dengan model PBL dapat merangsang mahasiswa dalam mengembangkan berpikir kritis dan aktivitas mahasiswa. Mahasiswaakan 
menjelaskan masalah nyata dan mengkonstruk pemahaman mahasiswa berdasarkan masalah yang mereka teliti, sehingga mahasiswa lebih mudah memahami konsep-konsep yang dipelajari dan meningkatkan pemaham konsep mahasiswa.

\section{PENUTUP}

\section{Kesimpulan}

Berdasarkan paparan data dan pembahasan yang telah diuraikan dapat diambil kesimpulan bahwa penerapan model Problem Based Learning (PBL) dalam pembelajaran pengembangan kurikulum adalah sebagai berikut.Penerapan model PBL pada tahapan pembelajaran merencanakan kerjasama akan melatih siswa dalam untuk mengorganisasikan tugas dan merencanakan penyelidikan yang dilakukan siswa, tahapan implementasi juga melatih siswa untuk berpikir, melalui observasi, pengamatan untuk mendapatkan penjelasan dan pemecahan masalahnya, selanjutnya mahasiswa akan menganalisis KD-KD pada kurikulum 2013 yang diperoleh dari hasil penelitian dengan membuat suatu laporan hasil pemetaan pada siklus I dan laporan penyusunan indikator dan tujuan pembelajaran pada siklus II dan mempersiapkan penyampaikan hasil penyelidikan melalui proses presentasi, ada proses evaluasi proses sehingga bisa diketahui refleksi dari mahasiswa dari proses kerja yang dilakukan oleh mahasiswa. Pemahaman konsep mahasiswa pada matakuliah pengemabangan kurikulum pada Siklus I mencapai $84,375 \%$ termasuk dalam kategori baik. Siklus II pemhaman konsep mencapai $95 \%$ dalam sangat baik, berdasarkan data tersebut menunjukkan bahwa model PBL dapat meningkatkan pemahaman konsep sebesar 10,62\%.

Penerapan model PBL, juga melatih aktivitas mahasiswa, pada semua tahapan pembelajaran mulai dari tahap orientasi siswa kepada masalah, mahasiswa difasilitasi menemukan topik yang akan dipelajari oleh mahsiswa, sampai dengan mengumpulkan data, menganalisis dan mengkomunikasikan hasil penyelidikan akan meningkatkan aktivitas mahasiswa, penilaian dilakukan dengan melakukan observasi selama kegiatan pembelajaran. Berdasarkan data tersebut menunjukkan bahwa model PBL dapat meningkatkan skor aktivitas mahasiswa sebesar 14,321\%.

\section{Saran}

Berdasarkan pembahasan, maka saran yang diajukan dirumuskan sebagai berikut. Penerapanmodel PBL, tidak bisa pelaksanaan dilakukan secara mandiri sepenuhnya oleh mahasiswa. Mahasiswa masih perlu pembimbingan dari dosen untuk mengarahkan mahasiswa sehingga 
pada saat pembelajaran berlangsung perhatian mahasiswa hanya terfokus pada kegiatan pembelajaran saja.

Pelaksanaan pembelajaran dengan model PBL, harus memperhatikan alokasi waktu. Manajemen waktu perlu diatur seefektif mungkin untuk mengurangi adanya penambahan waktu berlebih untuk pembelajaran.Pembelajaran secara konstektual akan mengembangkan berpikirmahasiswa, sehingga dosen sebagai pembimbing harus mempunyai persiapan materi yang lebih kompleks sebagai antisipasi pendapat ataupun pertanyaan yang muncul dari mahasiswa.

\section{DAFTAR RUJUKAN}

Arends, R.I. 2008. Learning to Teach: Belajar untuk Mengajar. Yogyakarta: Pustaka Pelajar.

Hasibuan, dan Moedjiono. 2008. Proses Belajar Mengajar. Bandung: PT Remaja Rosdakarya
Jamaluddin. 2009. Pengaruh Pembelajaran Pemberdayaan

Berpikir Melalui Pertanyaan

Dipadukan dengan Strategi Kooperatif dan Kemampuan Akademik terhadap Keterampilan Metakognisi, Berpikir Kreatif, Pemahaman Konsep IPA-Biologi, dan Retensi SD di Mataram. Disertasi tidak diterbitkan. Malang: PPs UM.

Muslikhatin. 2005. Penerapan PBL melalui GI dapat Meningkatkan Kemampuan Berpikir dan Hasil Belajar Biologi Mahasiswa Kelas X SMA Lab UM. Sripsi tidak diterbitkan. Malang: Jurusan Biologi FMIPA UM.

Nurhadi, dan Senduk, Gerrad A. 2004. Pembelajaran Kontekstual dan Penerapnnya dalam KBK. Malang: UM

Suzana, Y. (2004). Pembelajaran dengan Pendekatan Metakognitif untuk Meningkatkan Kemampuan Pemahaman Matematik Siswa SMU. Disajikan pada Seminar Nasional Matematika: Matematika dan Kontribusinya terhadap Peningkatan Kualitas SDM dalam Menyongsong Era Industri dan Informasi, Bandung, 15 Mei 2004.

Wena, Weda. 2009. Stategi Pembelajaran Inovatif Kontemporer. Jakarta: Bumi Aksara 